\title{
BMC reproductive health: family planning global conference series
}

\author{
Michael T Mbizvo ${ }^{1}$ and Anne Burke ${ }^{2^{*}}$
}

\section{Editorial}

Despite known benefits of modern contraception and family planning, especially in protecting the health of women and asserting their reproductive rights, more than 225 million women around the globe have an unmet need for wanting to avoid an unintended pregnancy [1]. Family planning could prevent up to $30 \%$ of the more than 287,000 maternal deaths that take place globally every year [2], with low and middle income countries accounting for up to $99 \%$ of the deaths.

The global conference series: International Family Planning Conference, first launched in Uganda in 2009, brought focus to research that is required to guide contraceptive method mix, improve quality of care, expand contraceptive access, family planning programming and coverage, as well as aid the development of new methods to meet the evolving needs of both new and current users. The subsequent 2012 London Family Planning Summit and its follow-on Family Planning 2020 initiative, further renewed impetus on family planning, with high-level policymaking buy-in. At this Summit, significant global and national commitments were made. These global developments require complementary scientific endeavour that can inform policy formulation and family planning program development or strengthening. A platform dedicated to sharing state of the art research ensures a scientific and policy environment that is responsive to critical elements for sustainable development. Implementation science research further ensures the identification of barriers to contraceptive method uptake and elaboration of factors associated with method switching or discontinuation.

Improving quality of care in family planning service delivery for example, through accessible expanded method-mix, as well as the training and wider distribution of providers, e.g. through skilled community distributors, as part of task shifting [3-5] are among

\footnotetext{
* Correspondence: aburke@jhmi.edu

${ }^{2}$ Department of Population, Family, Reproductive Health, Johns Hopkins Bloomberg School of Public Health, Bayview Medical Center, 4940 Eastern Avenue, 21224 Baltimore, MD, USA

Full list of author information is available at the end of the article
}

key determinates of improving contraceptive prevalence rate $(\mathrm{CPR})$. The premise that underpins increasing $\mathrm{CPR}$ is that improved quality of family planning services, e.g., through widening contraceptive choice, providing full information and counseling, based on plausible research findings, and client satisfaction with method, are among key determinants of contraceptive uptake and method use continuation. Full contraceptive access also requires provision of services to women across the reproductive lifespan, from adolescents to adulthood. The papers presented in this thematic series reflect a focus on some of these important considerations.

This series collates some of the papers presented during the 2013 International Family Planning Conference, which was attended by over 3,500 researchers, program implementers, policy makers, advocates, youth leaders and media and representatives of local and international organizations from 110 countries. The conference reflected on the theme "Full Access, Full Choice" to life saving Family Planning information, supplies and service. The papers presented all have the objective of responding to the contraceptive needs of the millions of women which in some instances, is a matter of survival or death.

These responses can take a variety of approaches, including harnessing mobile health technology to support family planning access in Cambodia (Smith et al. [6]), and assessing feasibility of contraceptive service integration into the workload of community health workers in Rwanda (Chin Quee et al. [7]). Understanding women's fertility desires and contraceptive needs, as explored among women in 3 peri-urban communities in sub-Saharan Africa (OlaOlorun et al. [8]), is an important component in the evolution of successful family planning programs. And we must understand the contraceptive needs of women at all stages of reproductive life, which reflect a growing recognition of the importance of youth- and adolescent-friendly reproductive health services as espoused in an analysis of data from 8 low- and middle-income countries in the 
paper by Chandra-Mouli et al. [9]. These studies are part of the global to effort to advance sexual and reproductive health through, among other things, appropriately addressing the wider contraceptive needs of women and couples throughout the reproductive life span.

\section{Competing interests}

The authors declare that they have no competing interests.

\section{Authors' contributions}

MTM and AB both drafted and edited the manuscript. Both authors read and approved the final manuscript.

\section{Author details}

'Population Council, Reproductive Health \& Research, WHO/HQ, College of Health Science, University of Zimbabwe, Geneva, Switzerland. ${ }^{2}$ Department of Population, Family, Reproductive Health, Johns Hopkins Bloomberg School of Public Health, Bayview Medical Center, 4940 Eastern Avenue, 21224

Baltimore, MD, USA.

Received: 5 January 2016 Accepted: 5 January 2016

Published online: 06 February 2016

\section{References}

1. Sing S, Darroch JE, Ashford LS. Adding it up: The cost and benefits of investing in sexual and reproductive health 2014". New York: Guttmacher Institute; 2014.

2. WHO, UNICEF, UNFPA. The World Bank and the United Nations Population Division. Trends in Maternal Mortality: 1990 to 2013. Geneva: World Health Organization; 2014.

3. MC Poke B, Mensoh K. Task Shifting in Health Care in resource-poor countries. Lancet. 2008;372(9642):870-1.

4. Sing P, Sachs TD. 1 Million Community Health Workers in sub-Sahara Africa by 2015. Lancet. 2013;382(9887):363-5.

5. World Health Organization (WHO). Task Shifting: rational redistribution of tasks among health workforce teams: Global recommendations and guidelines. WHO. Geneva 2008. Accessed http://www.who.int/ healthsystems/TTR-TaskShifting.pdf.

6. Smith C, Vannak U, Sokhey L, Ngo TD, Gold J, Free C. Mobile Technology for Improved Family Planning (MOTIF): the development of a mobile phonebased (mHealth) intervention to support post-abortion family planning (PAFP) in Cambodia. BMC Repro Health (issue details needed).

7. Chin-Quee D, Mugeni C, Nkunda D, Uwizeye MR, Stockton LL, Wesson J. Balancing workload, motivation and job satisfaction in Rwanda: assessing the effect of adding family planning service provision to community health worker duties. BMC Repro Health (issue details needed).

8. OlaOlorun F, Seme A, Otupiri E, Ogunjuyigbe P, Tsui A. Do Women's Fertility Desires Influence Contraceptive Behavior?: Findings from Three Peri-urban Communities in Sub Saharan Africa. BMC Repro Health (issue details needed).

9. Chandra-Mouli V, Chatterjee S, Bose K. Do efforts to standardize, assess and improve the quality of health service provision to adolescents by government-run health services in low and middle income countries, lead to improvements in service-quality and service-utilization by adolescents? BMC Repro Health (issue details needed).

Submit your next manuscript to BioMed Central and we will help you at every step:

- We accept pre-submission inquiries

- Our selector tool helps you to find the most relevant journal

- We provide round the clock customer support

- Convenient online submission

- Thorough peer review

- Inclusion in PubMed and all major indexing services

- Maximum visibility for your research

Submit your manuscript at www.biomedcentral.com/submit
Biomed Central 